\title{
PERAN SUASANA HATI, HARGA DIRI DAN SIKAP TENTANG UANG DALAM MEMPENGARUHI PERILAKU PEMBELIAN KOMPULSIF : STUDI EMPIRIS PADA MAHASISWA DI KOTA SEMARANG
}

\author{
Kemal Budi Mulyono ${ }^{1)}$, Rusdarti ${ }^{2)}$, Ubaedul Mustofa ${ }^{3)}$ \\ Fakultas Ekonomi, Universitas Negeri Semarang \\ sonmuly@mail.unnes.ac.id ${ }^{1)}$,rusdarti@mail.unnes.ac.id ${ }^{2)}$, \\ ubaed_almustafa@mail.unnes.ac.id ${ }^{3)}$
}

\begin{abstract}
Young people often have fast and underdeveloped decisions, one of which is irrational consumption activities such as compulsive purchases. Some research shows the occurrence of compulsive buying behavior, one of which is due to psychological factors. This study aims to reveal how moods, self-esteem, and attitudes about student money can influence compulsive buying behavior. The data in the study was taken through a measurement scale questionnaire on public or private students in an incidental way to 100 students in the city of Semarang, then with Warp PLS based inferential statistics. From the results of the study showed that mood, self-esteem, a positive effect on compulsive purchases, attitudes about money while negatively affecting compulsive purchases. The implications of this research are psychological factors, it should be controlled through student learning maturity towards personal behavior.
\end{abstract}

Keywords: Mood, Attitude About Money, Self-esteem, Compulsive Buying.

\begin{abstract}
Abstrak
Usia muda sering kali memiliki pengambilan keputusan yang cepat dan kurang matang, salah satunya dalam melakukan kegiatan konsumsi irasional seperti pembelian kompulsif. Beberapa riset menunjukkan terjadinya perilaku pembelian kompulsif, salah satunya karena persoalan faktor-faktor psikologi. Penelitian ini bertujuan untuk mengungkap bagaimana suasana hati, harga diri, dan sikap tentang uang mahasiswa dapat berpengaruh terhadap perilaku pembelian kompulsif. Data dalam penelitian diambil melalui kuesioner skala pengukuran pada mahasiswa negeri ataupun swasta secara insidental terhadap 100 mahasiswa di Kota Semarang, kemudian dengan statistik inferensial berbasis Warp PLS. Dari hasil penelitian menunjukkan bahwa suasana hati, harga diri, berpengaruh positif terhadap pembelian kompulsif, sikap tentang uang sementara berpengaruh negatif terhadap pembelian kompulsif. Implikasi dari penelitian ini adalah faktor-faktor psikologi tersebut, seharusnya dapat dikontrol melalui kematangan belajar mahasiswa terhadap perilaku pribadinya.
\end{abstract}

Kata Kunci: Suasana Hati, Sikap Tentang Uang, Harga Diri, Pembelian Kompulsif. 


\section{PENDAHULUAN}

Pesatnya kemajuan teknologi saat ini memunculkan kebiasaan serta gaya hidup juga berubah dalam waktu yang relatif singkat menuju kearah semakin mewah dan berlebihan. Fenomena belanja online yang sangat mudah tersebut mendorong terjadinya perilaku pembelian secara kompulsif (berbelanja secara berlebihan) dikalangan remaja khususnya mahasiswa, yang tidak lagi untuk memenuhi kebutuhan tetapi karena ketidakmampuan mengendalikan hasrat untuk membeli sesuatu akan mendorong mereka untuk melakukan apa saja asalkan hasrat tersebut dapat terpenuhi (Lejoyeux \& Weinstein, 2010). Pembelian kompulsif merupakan suatu fenomena psikoekonomik yang banyak melanda kehidupan masyarakat terutama yang tinggal di perkotaan. Pembelian kompulsif dapat diartikan sebagai suatu bentuk pembelian dengan kontrol yang lemah atau berlebihan, dorongan yang berkenaan dengan pembelanjaan dan pengeluaran, yang konsekuensinya bersifat merugikan (Black, 2001). Pembeli kompulsif rata-rata berada dalam usia remaja atau mahasiswa (Faber et al., 1994). Pembelian kompulsif merupakan permasalahan sangat penting untuk dikaji dicari solusi pemecahannya karena mempunyai pengaruh negatif baik pada konsumen sendiri maupun pada masyarakat luas, khususnya mahasiswa.

Akar permasalahan munculnya pembelian kompulsif salah satunya ditimbulkan dari faktor psikologis dimana pembelian kompulsif terutama memiliki sifat penguat negatif dan digunakan untuk melarikan diri dari perasaan negatif seperti kecemasan, depresi, ketegangan, atau kebosanan. pembelian kompulsif juga dapat dianggap sebagai kegagalan kronis dan berulang dalam regulasi mandiri (Kellet \& Bolton, 2009). Biasanya ada hubungan dengan tingkat impulsif tinggi pada individu dengan pembelian kompulsif yang menyebabkan hilangnya kendali atas pengeluaran. (Billieux et al, 2008) Selain itu, dukungan nilai-nilai material, depresi, harga diri rendah, perfeksionisme, kesulitan pengambilan keputusan dan narsisme telah terbukti terkait dengan pembelian kompulsif. (Dittmar, 2005; Kyrios, et al, 2004) Bukti empiris menunjukkan bahwa mereka yang membeli secara kompulsif mewakili kelompok yang heterogen. Temuan dari beberapa investigasi menunjukkan kluster yang berbeda dengan kecenderungan disposisi yang unik dan mempertahankan faktor psikologis yang mengarah pada pembelian kompulsif. Sebagian besar penelitian mengidentifikasi kluster pembelian pertama, lebih parah, kompulsif dengan komorbiditas psikiatris tinggi dan penguatan negatif sebagai motif untuk membeli, sedangkan klaster kedua lebih banyak terkait dengan motif penguatan positif untuk membeli, dan termasuk individu dengan psikopatologi rendah.Berdasarkan latar belakang yang telah diuraikan sebelumnya maka, rumusan masalah dalam penelitian ini adalah mengidentifikasi factor psikologis dan faktor sosial penentu dari perilaku compulsive buying (pembelian kompulsif).

\section{Perilaku Pembelian Kompulsif}

O'Guinn dan Faber, 1989 mendefinisikan pembelian kompulsif sebagai "Respons terhadap dorongan yang tidak terkendali atau keinginan untuk memperoleh, menggunakan, atau mengalami suatu perasaan, substansi atau kegiatan yang menuntun individu untuk secara berulang kali terlibat dalam perilaku yang akhirnya merugikan individu atau individu lain. Perilaku pembelian kompulsif adalah perilaku pembelian yang berulang dan akut, yang menjadi respon utama untuk menghadapi perasaan atau kejadian yang tidak menyenangkan seperti sedih, depresi, 
frustrasi, dan lain-lain serta perilaku pembelian kompulsif ini menjadi salah satu tujuan utama yaitu perbaikan suasana hati. O'Guinn dan 'Faber (1989) menemukan bahwa pembeli kompulsif cenderung menunjukkan kompulsivitas sebagai sifat kepribadian dan memiliki harga diri dan fantasi yang lebih rendah serta konsekuensi dari pembelian kompulsif adalah tingkat ekstrem. Menurut O'Guinn dan Faber (1989) Konsumsi kompulsif (compulsive buying) memiliki ciri-ciri : 1) Mempunyai keinginan yang kuat untuk mendapatkan sesuatu; 2) Mempunyai keinginan kuat untuk menggunakan barang yang baru; 3) Adanya perasaan yang tidak terkontrol untuk melakukan pembelian; 4) Biasa pergi berbelanja setiap kali muncul dorongan untuk melakukan pembelian. Biasa membeli lebih dari satu barang dalam sekali berbelanja.

\section{Harga Diri}

Harga diri (Self-esteem) didefinisikan sebagai sikap positif atau negatif terhadap diri.Harga diri (Self-esteem) dapat dilihat sebagai indikator kunci dari kesejahteraan psikologis.Harga diri dalam budaya barat biasanya berbeda berdasarkan jenis kelamin.Tingkat harga diri atau gengsi seorang perempuan biasanya lebih tinggi bila dibandingkan dengan tingkat harga diri seorang laki-laki (Clayetal, 2005). Menurut Myres, (2012) harga diri adalah pendapat personal seseorang tentang nilai dirinya, berdasarkan atas apakah perilakunya telah sesuai dengan ideal diri dan evaluasi seseorang tentang dirinya. Menurut Baron dan Branscombre, (2014) Harga diri sebagai evaluasi atau penilaian diri yang dibuat oleh setiap individu dan merupakan sikap seseorang terhadap dirinya sendiri dalam rentang positif-negatif. Gora (2011) juga menjelaskan bagaimana seseorang menilai dirinya sendiri tergantung pada tingkat harga diri yang dimiliki. Harga diri seseorang menunjukkan seberapa besar ia akan menghargai dirinya sendiri. Harga diri yang sehat mengarah ke kemerdekaan, kebahagiaan, fleksibilitas, dan kemampuan untuk beradaptasi dengan mudah untuk mengubah, bekerjasama dan pandangan positif pada setiap situasi begitu juga sebaliknya. Beberapa penelitian telah secara signifikan menghubungkan harga diri dengan perilaku pembelian kompulsif. Seseorang dengan harga diri yang rendah melaporkan lebih banyak keadaan emosi negatif, kecemasan yang lebih tinggi dan tingkat stres yang lebih tinggi (Brown dan Marshall, 2001; Cast dan Burke, 2002). Berdasarkan dari penelitian - penelitian tersebut maka dapat dirumuskan hipotesis

$\mathrm{H}_{1}$ : Ada pengaruh harga diri terhadap perilaku pembelian kompulsif

\section{Sikap tentang uang (Money Attitude)}

Uang adalah elemen penting dalam kehidupan kita sehari-hari. Ini memotivasi orang dan memengaruhi keputusan pembelian mereka. Individu tidak hanya mengaitkan nilai, utilitas, dan kekayaan dengan uang, mereka juga mengaitkan berbagai makna dan emosi dengan uang (Belk \& Wallendorf, 1990; Yamauchi \& Templer, 1982). Ekonom biasanya menganggap individu sebagai pembuat keputusan rasional dan dengan demikian individu harus selalu berusaha meningkatkan kekayaan mereka dan memaksimalkan utilitas yang dihasilkan dari uang. Namun, seperti halnya individu juga tujuan penting lainnya (mis. memperoleh kekuasaan, menikmati hidup) selain mengumpulkan kekayaan, tujuan-tujuan ini secara keseluruhan memengaruhi sikap individu terhadap uang dan keputusan serta perilaku mereka yang melibatkan uang. Dengan demikian, makna simbolik uang menjadi penting aspek uang dan bahkan mungkin melebihi nilai ekonomisnya (Medina et al., 1996). Literatur 
mendokumentasikan bahwa sikap uang adalah konstruksi multidimensi dan individu menghubungkan makna simbolik yang berbeda dengan uang (Medina et al., 1996). Berdasarkan beberapa penelitian tersebut maka dapat disimpulkan bahwa .

$\mathrm{H}_{2}$ : Ada pengaruh sikap tentang uang terhadap perilaku pembelian kompulsif

\section{Suasana Hati}

Meskipun ada bukti perubahan suasana hati di sekitar satu dari empat konsumen umum selama akuisisi, di pembelian kompulsif pengalaman perubahan suasana hati muncul di mana-mana (Faber \& Christenson, 1996) dan biasanya perubahan suasana hati menuju pengaruh positif dan menjadi keadaan gairah tinggi (McElroy et al., 1994) atau bantuan / kepuasan (Christenson et al., 1994). Beberapa penelitian menggambarkan bahwa pembeli kompulsif secara retrospektif melaporkan perubahan suasana hati yang lebih besar dari sebelumnya menjadi segera setelah pembelian daripada kontrol (Dittmar 2005). Pandangan bahwa pembelian secara kompulsif digunakan sebagai mekanisme pengaturan suasana hati untuk mengubah yang negatif suasana hati menjadi lebih positif telah menemukan dukungan dalam banyak penelitian. Ini telah disebut 'hipotesis pengobatan dan konsisten di sebagian besar studi (Vohs \& Faber, 2007; Kellett \& Bolton, 2009; McElroy, Keck, Pope, Smith \& Strakowski, 1994). Berdasarkan beberapa penelitian tersebut maka dapat disimpulkan bahwa .

$\mathrm{H}_{3}$ : Ada Pengaruh suasana hati terhadap perilaku pembelian kompulsif

Berdasarkan kerangka berfikir pengembangan hipotesis yang telah diuraikan sebelumnya, maka dapat di gambarkan kerangka penelitian empiris sebagai berikut:

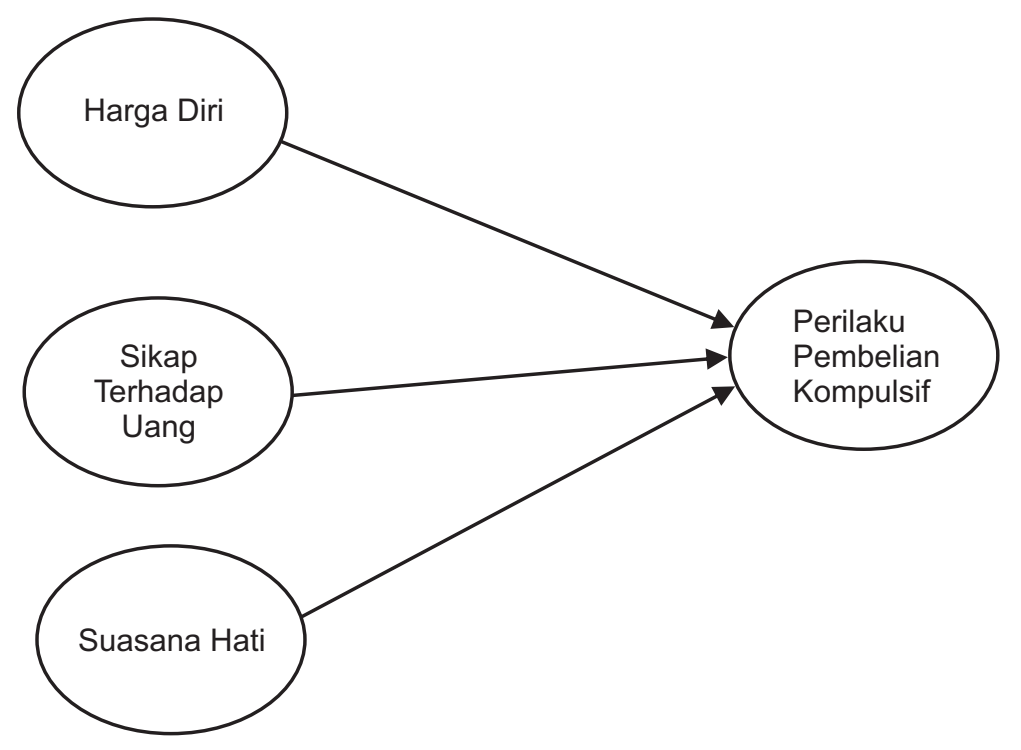

Gambar 1. Model Empiris Penelitian

Sumber: Penelitian-penelitian terdahulu dikumpulkan tahun 2019

\section{METODE PENELITIAN}

Desain penelitian yang digunakan penulis adalah desain asosiatif yang dirancang melalui langkah-langkah penelitian dari operasional variabel, penentuan jenis dan sumber data, metode pengumpulan data dan diakhiri dengan rancangan pengujian hipotesis dan statistik, dengan lokasi penelitian mengambil tempat Universitas Negeri ataupun 
universitas swasta di Kota Semarang. Data yang digunakan dalam penelitian ini adalah data primer yang diperoleh dalam penyebaran angket penelitian dengan menggunakanskala interval aggre disagree. Dimana setiap item soal disediakan rentangan skala 1-5 dengan sudut ekstrim SS sangat setuju dan STS sangat tidak setuju kepada para responden yang terdiri dari mahasiswa yang belajar ekonomi baik difakultas ekonomi ataupun fakultas ilmu keguruan dan pendidikan, dimana menggunakan sampel untuk populasi yang tidak diketahui. Metode pengambilan sampel dalam penelitian ini menggunakan rumus sampel dimana populasi tidak diketahui jumlahnya, yaitu dengan rumus lameshow dengan batas error margin 0,05 persen atau nilai $\mathrm{Z}$ sebesar 1,96 sebagai berikut $\rightarrow \mathrm{n}=\left(\mathrm{Z}^{\wedge} 2 \mathrm{p}(1-\mathrm{p})\right) / \mathrm{d}^{\wedge} 2$. Sehingga didapatkan jumlah besaran sample sebesar 100 responden. Pengukuran terhadap masingmasing variabel berbasis adalah sebagai berikut.

1) Perilaku pembelian kompulsif diukur dengan dimensi utama yaitu perilaku pembelian kompulsif obsesive, dan pembelian impulsif (Edwards, 1993).

2) Harga diri dengan pengukuran Skala 10item yang mengukur harga diri global dengan mengukur perasaan positif dan negatif tentang diri (Rosenberg, 1965).

3) Sikap tentang uang diukur dengan mengidentifikasi lima faktor yang menggambarkan hubungan dengan uang yaitu Power-Prestige, Retention Time Ketidakpercayaan Kecemasan, ketakutan akan kehilangan peluang bagus untuk membeli barang (Yamauchi \& Templer's, 1982).

4) Suasana hati diukur dengan indikator aktivasi tinggi positif (antusias, bersemangat, ceria), aktivasi rendah positif (tenang, santai, damai), aktivasi tinggi negatif (cemas, bermusuhan, stres), dan aktivasi rendah negatif (sedih, depresi, sedih) (Barrett \& Russell, 1999).

Hal pertama yang dilakukan untuk memperoleh konstruksi skala pengukuran yang baik, dilakukan pilot tes, hasil dari pilot test kemudian dijadikan acuan dalam uji lapangan. Setelah data terkumpul dari lapangan selanjutnya dilakukan: Analisis validitas dan reliabilitas konstrukdengan menggunakan WARP PLS 6.0. Kemudian dilanjutkan pada analisis statistik inferensial dengan menggunakan WARP PLS - SEM yakni dengan (1) konseptualisasi model; (2) menentukan metode analalisis alogarthm; (3) menentukan metode resampling, (4) menggambarkan diagram jalur; (5) mengevaluasi dan mengistimasi inner model, ataupun outer model, dengan alogaritma Warp PLS mode A basic, untuk diketahui nilai $\mathrm{t}$ statistik dan (6) melaporkan hasil analisis sementara. (Ghozali\& latan, 2014).

\section{HASIL DAN PEMBAHASAN \\ Hasil}

Tingkat pengembalian angket dalam hal ini adalah $90 \%$ dari 200 angket yang disebar pada selurus responden yang kembali ataupun dapat diolah adalah 180 responden. Kemudian dari kuesioner tersebut, dilakukan tabulasi, dari hasil tabulasi dihitung berdasarkan statistik deskriptif lalu dikategorikan menjadi 5 kategori yaitu pada kategori (sangat tinggi, tinggi, sedang, rendah, dan sangat rendah) dengan masingmasing rentang interval yang disesuaikan dengan jumlah item pada masing-masing variabel.dari analisis tersebut dapat disimpulkan sebagai berikut. 
Tabel 1.

Hasil Deskriptif perVariabel

\begin{tabular}{lll}
\hline Variabel & Skor rata-rata & Kategori \\
\hline Perilaku pembelian kompulsif & 27,10989011 & Rendah \\
Suasana hati & 51,64835165 & Sangat tinggi \\
Harga diri & 30,73626374 & Tinggi \\
Sikap tentang uang & 35,91208791 & Sedang \\
\hline
\end{tabular}

Sumber: Hasil Penelitian diolah tahun 2019

Dari hasil statistik deskriptif di atas dapat dijelaskan bahwa dari seluruh responden diatas memiliki beberapa karakteristik yang terkategori dalam beberapa variabel. Pada perilaku pembelian kompulsif, dapat ditunjukkan ternyata mahasiswa di Kota Semarang, memang tidak memiliki perilaku pembelian kompulsif yang tinggi, artinya dalam konteks ini pembelian kompulsif mereka memiliki rata-rata rendah, walaupun juga ada beberapa yang tinggi, karena berbasis pada nilai rata-rata. Sementara, untuk suasana hati memiliki skor yang sangat tinggi, artinya memang suasana hati yang dimiliki oleh mahasiswa sedang sangat baik/bahagia. Untuk harga diri ternyata memiliki rata-rata tinggi, hal ini menunjukkan bahwa harga diri yang dimiliki oleh mahasiswa di Kota Semarang adalah dalam kategori yang tinggi. sementara sikap mereka terhadap uang sedang, artinya mereka memang tidak terlalu bersikap menghamburhamburkan uang, tetapi juga tidak terlalu baik dalam mengelola uang.

Setelah dilakukan perhitungan statistik deskriptif, kemudian data penelitian tersebut dilanjutkan pada pengujian atau analisis pada outer model yang terdiri dari uji validitas dan reliabilitas konstruk. Untuk pengujian validitas konstruk maka diuji validitas konvergen dan validitas diskriminan, sementara untuk reliabilitas konstruk diuji yang berbasis pada nilai alpha cronbach dan composite reliabilityadapun hasil pengujian pada outer model dapat disajikan dalam tabel sebagai berikut.

Tabel 2

Uji Outer Model

\begin{tabular}{l|l|c|c|c|}
\hline Variabel Item & $\begin{array}{l}\text { Loading } \\
\text { faktor }\end{array}$ & AVE & $\begin{array}{l}\text { Alpha } \\
\text { Cronbach }\end{array}$ & $\begin{array}{l}\text { Compo- } \\
\text { site } \\
\text { Reliabi- } \\
\text { lity }\end{array}$ \\
\hline Perilaku Pembelian Kompulsif & & & \\
1. Senang berbelanja & 0.569 & 0.585 & 0.824 & 0.867 \\
2. Berbelanja walaupun tidak membutuhkan & 0.778 & & & \\
3. Terus berbelanja walaupun mengalami & 0.808 & & & \\
$\quad$ masalah keuangan & & & \\
4. Berbelanja lebih dari pendapatan & 0.589 & & \\
5. Berbelanja terhadap barang yang & 0.684 & & \\
$\quad$ sama walaupun belum pernah dipakai & & & \\
$\quad$ sebelumnya & & & \\
6. Dianggap sebagai 'shopaholic'. & & & \\
7. Tidak merencanakan ketika berbelanja & 0.709
\end{tabular}




\begin{tabular}{|c|c|c|c|c|}
\hline Variabel Item & $\begin{array}{l}\text { Loading } \\
\text { faktor }\end{array}$ & AVE & $\begin{array}{l}\text { Alpha } \\
\text { Cronbach }\end{array}$ & $\begin{array}{l}\text { Compo } \\
\text { site } \\
\text { Reliabi- } \\
\text { lity }\end{array}$ \\
\hline \multicolumn{5}{|l|}{ Suasana Hati } \\
\hline $\begin{array}{l}\text { 1. bereaksi dengan rasa takut atau cemas } \\
\text { terhadap berbagai peristiwa dalam } \\
\text { hidup }\end{array}$ & 0.685 & 0.542 & 0.780 & 0.780 \\
\hline $\begin{array}{l}\text { 2. percaya dengan hal-hal yang membuat } \\
\text { orang lain akan suka }\end{array}$ & 0.732 & & & \\
\hline 3. sering menekan diri sendiri & 0.788 & & & \\
\hline \multicolumn{5}{|l|}{ Sikap tentang uang } \\
\hline $\begin{array}{l}\text { 1. menganggap uang sebagai simbol utama } \\
\text { kesuksesan }\end{array}$ & 0.785 & 0.541 & 0.797 & 0.796 \\
\hline $\begin{array}{l}\text { 2. memiliki barang-barang untuk } \\
\text { mengesankan orang lain }\end{array}$ & 0.718 & & & \\
\hline $\begin{array}{l}\text { 3. berdebat dan mengeluh tentang harga } \\
\text { barang yang dibeli }\end{array}$ & 0.562 & & & \\
\hline 4. khawatir tidak akan aman secara finansial & 0.619 & & & \\
\hline 5. Sulit bagi untuk melewatkan tawaran & 0.614 & & & \\
\hline \multicolumn{5}{|l|}{ Harga Diri } \\
\hline 1. puas dengan diri sendiri. & 0.716 & 0.557 & 0.792 & 0.833 \\
\hline 2. merasa memiliki kualitas baik & 0.670 & & & \\
\hline $\begin{array}{l}\text { 3. dapat melakukan hal-hal seperti } \\
\text { kebanyakan orang lain }\end{array}$ & 0.550 & & & \\
\hline $\begin{array}{l}\text { 4. merasa menjadi orang yang berharga, } \\
\text { sama dengan orang lain. }\end{array}$ & 0.677 & & & \\
\hline $\begin{array}{l}\text { 5. mengambil sikap positif terhadap diri } \\
\text { sendiri. }\end{array}$ & 0.694 & & & \\
\hline 6. cenderung merasa bahwa saya gagal & 0.732 & & & \\
\hline
\end{tabular}

Sumber: Hasil Penelitian diolah tahun 2019

Hasil outer model menunjukkan bahwa setiap variabel item tersebut, memenuhi kriteria validitas konvergen, yaitu setiap loading faktor dari setiap item di atas cut value di atas 0,5 . Sementara itu dari hasil validitas diskriminan dapat dilihat dari nilai Average Variance Extracted (AVE) di atas cut value 0,5 . Sementara itu, reliabilitas penelitian yang terdiri dari berbasis alpha cronbach dan composite reliability berada di atas 0,7 , sehingga dapat disimpulkan bahwa seluruh variabel adalah reliabel.Sehingga dapat dinyatakan seluruh item tersebut dapat membentuk konstruk-konstruk pada variabel tersebut baik pada perilaku pembelian kompulsif, suasana hati, sikap tentang uang, dan harga diri. Selanjutnya dalam penelitian ini dilanjutkan pada uji inner model (uji goodness of fit dan uji t/hipotesis).

Uji goodness of fit, dalam penelitian ini terdiri dari beberapa analisis yaitu average path coefficient (APC), average R-squared (ARS), average adjusted R-squared (AARS), average block VIF (AVIF), average full collinearity VIF (AFVIF), tenenhaus GoF (GoF), sympson's paradox ratio (SPR), r-squared contribution ratio (RSCR), statistical suppression ratio (SSR), nonlinear bivariate causality direction ratio (NLBCDR). Adapun hasil gooness of fit adalah sebagai berikut. 
Tabel 3.

Model Fit And Quality Indices

\begin{tabular}{|c|c|c|c|}
\hline Uji Goodness of Fit & Nilai & Cut Value & Kriteria \\
\hline Average path coefficient (APC) & $\begin{array}{l}0.311 \text {, dengan } \\
\mathrm{P}<0.001\end{array}$ & $\mathrm{P}<0.05$ & Baik \\
\hline Average R-squared (ARS) & $\begin{array}{l}0.371 \\
\mathrm{P}<0.001\end{array}$ & $\mathrm{P}<0.05$ & Baik \\
\hline Average adjusted R-squared (AARS) & $\begin{array}{l}0.350 \\
\mathrm{P}<0.001\end{array}$ & $\mathrm{P}<0.05$ & Baik \\
\hline Average block VIF (AVIF) & 1.024 & $\begin{array}{l}\text { acceptable if }<= \\
5, \text { ideally }<=3.3\end{array}$ & Ideal \\
\hline Average full collinearity VIF (AFVIF) & 1.200 & $\begin{array}{l}\text { acceptable if }<= \\
5, \text { ideally }<=3.3\end{array}$ & Baik \\
\hline Tenenhaus GoF (GoF) & 0.423 & $\begin{array}{l}\text { small }>=0.1, \\
\text { medium }>= \\
0.25, \text { large }>= \\
0.36\end{array}$ & $\begin{array}{l}\text { Large / } \\
\text { besar }\end{array}$ \\
\hline Sympson's paradox ratio $(\mathrm{SPR})=$, & 1.000 & $\begin{array}{l}\text { acceptable if }>= \\
0.7, \text { ideally }=1\end{array}$ & Ideal \\
\hline $\mathrm{R}$-squared contribution ratio $(\mathrm{RSCR})=1.000$ & 1.000 & $\begin{array}{l}\text { acceptable if }>= \\
0.9, \text { ideally }=1\end{array}$ & Ideal \\
\hline Statistical suppression ratio (SSR) & 1.000 & $\begin{array}{l}\text { acceptable if }>= \\
0.7, \text { ideally }=1\end{array}$ & Ideal \\
\hline $\begin{array}{l}\text { Nonlinear bivariate causality direction ratio } \\
\text { (NLBCDR) }\end{array}$ & 1.000 & $\begin{array}{l}\text { acceptable if }>= \\
0.7\end{array}$ & baik \\
\hline
\end{tabular}

Sumber : Hasil Penelitian diolah tahun 2019

Berdasarkan hasil dari uji goodness of fit pada model WARP PLS SEM, maka dapat dilihat bahwa dari seluruh kriteria uji goodness of fit baik dari average path coefficient (APC) sampai dengan nonlinear bivariate causality direction ratio (NLBCDR) memenuhi kriteria yang baik ataupun ideal.

Sehingga evaluasi atau tes pada inner model memenuhi kriteria WARP PLS SEM secara baik, selanjutnya dapat dilanjutkan pada pengujian hipotesis. Adapun hasil uji hipotesis dapat ditunjukkan dalam tabel berikut:

Tabel 4.

Uji Hipotesis

\begin{tabular}{lllll}
\hline \multicolumn{1}{c}{ Hipotesis } & Koefisien & $\begin{array}{l}\text { Standar } \\
\text { error }\end{array}$ & p-value & Keterangan \\
\hline $\begin{array}{l}\mathrm{H}_{1}: \text { Ada pengaruh harga diri terhadap } \\
\text { perilaku pembelian kompulsif }\end{array}$ & 0.244 & 0.098 & 0.007 & Diterima \\
$\begin{array}{l}\mathrm{H}_{2} \text { : Ada pengaruh sikap tentang uang } \\
\text { terhadap perilaku pembelian }\end{array}$ & -0.477 & 0.092 & $<0.001$ & Diterima \\
kompulsif & & & & \\
$\mathrm{H}_{3}$ : Ada Pengaruh suasana hati & 0.210 & 0.099 & 0.018 & Diterima \\
$\begin{array}{l}\text { terhadap perilaku pembelian } \\
\text { kompulsif }\end{array}$ & & & & \\
\hline
\end{tabular}

Sumber : Hasil Penelitian diolah tahun 2019 
Hasil dari uji hipotesis 1 bahwa ada pengaruh harga diri terhadap perilaku pembelian kompulsif secara empiris diterima. Dengan koefisien sebesar 0.244 , dan p value sebesar 0,007 di bawah 0,05. Sehingga dapat disimpulkan bahwa harga diri berpengaruh secara positif dan signifikan terhadap perilaku pembelian kompulsif, sehingga semakin tinggi harga diri maka semakin tinggi perilaku pembelian kompulsif. Pada uji hipotesis 2 bahwa ada pengaruh sikap tentang uang terhadap perilaku pembelian kompulsif secara empiris diterima. Dengan koefisien sebesar -0.477 , dan $p$ value sebesar $<0.001$ atau di bawah 0,05. Sehingga dapat disimpulkan bahwa sikap tentang uang berpengaruh secara negatif dan signifikan terhadap perilaku pembelian kompulsif, sehingga semakin tinggi sikap tentang uang maka semakin rendah perilaku pembelian kompulsif, begitu juga sebaliknya. Sementara untuk uji hipotesis 3 bahwa ada pengaruh suasana hati terhadap perilaku pembelian kompulsifsecara empiris diterima. Dengan koefisien sebesar 0.210 , dan $\mathrm{p}$ value sebesar 0.018 di bawah 0,05 . Sehingga dapat disimpulkan bahwa harga diri berpengaruh secara positif dan signifikan terhadap perilaku pembelian kompulsif, sehingga semakin tinggi harga diri maka semakin tinggi perilaku pembelian kompulsif.

\section{Pembahasan}

Harga diri secara empiris terbukti berpengaruh secara positif dan signifikan terhadap perilaku pembelian kompulsif. Hal ini menunjukkan bahwa semakin tinggi harga diri maka semakin tinggi pula perilaku pembelian kompulsif. Harga diri dari mahasiswa di kota Semarang berdasarkan dari hasil deskriptif adalah tinggi, hal tersebut dapat dimaknai mahasiswa di Kota Semarang memiliki karakteristik puas dengan diri sendiri, merasa memiliki kualitas baik, dapat melakukan hal-hal seperti kebanyakan orang lain, merasa menjadi orang yang berharga, mengambil sikap positif terhadap diri sendiri, cenderung merasa bahwa saya gagal memiliki kategori tinggi. Dan karakter tersebut ternyata berkencederungan dapat berdampak terhadap perilaku pembelian kompulsif mereka seperti senang berbelanja, berbelanja walaupun tidak membutuhkan, terus berbelanja walaupun mengalami masalah keuangan, berbelanja lebih dari pendapatan, berbelanja terhadap barang yang sama walaupun belum pernah dipakai sebelumnya, dianggap sebagai 'shopaholic', tidak merencanakan ketika berbelanja.

Hal tersebut dapat dipahami semakin orang memiliki atau merasa harga diri yang tinggi, biasanya mereka tidak rasional dalam menilai dirinya sendiri, dan hal tersebut menjadikan diri seseorang menjadi lebih tamak, ataupun menjadi lebih regresif terhadap sesuatu hal Myres, (2012). Harga diri sebagai evaluasi atau penilaian diri yang dibuat oleh setiap individu dan merupakan sikap seseorang terhadap dirinya sendiri dalam rentang positif-negatif Baron dan Branscombre, (2014), dimana seseorang menilai dirinya sendiri tergantung pada tingkat harga diri yang dimiliki. Harga diri seseorang menunjukkan seberapa besar ia akan menghargai dirinya sendiri. Sehingga orang yang memiliki harga diri yang tinggi cenderung untuk memiliki pandangan negatif pada setiap situasi termasuk juga pada perilaku konsumsinya Gora (2011).

Sikap tentang uang dalam hal ini adalah sikap terhadap penggunaan uang. Berdasarkan hasil uji hipotesis menunjukkan bahwa sikap mahasiswa terhadap penggunaan uang (sikap tentang uang) berpengaruh secara negatif dan signifikan terhadap perilaku pembelian kompulsif. Hal ini menunjukkan bahwa karakteristik sikap terhadap penggunaan uang (sikap tentang uang) seperti menganggap uang sebagai symbol utama kesuksesan, memiliki barang-barang untuk 
mengesankan orang lain, berdebat dan mengeluh tentang harga barang yang dibeli, khawatir tidak akan aman secara finansial sulit bagi untuk melewatkan tawaran, akan menurunkan perilaku pembelian kompulsif seperti senang berbelanja, berbelanja walaupun tidak membutuhkan, terus berbelanja walaupun mengalami masalah keuangan, berbelanja lebih dari pendapatan, berbelanja terhadap barang yang sama walaupun belum pernah dipakai sebelumnya, dianggap sebagai 'shopaholic', tidak merencanakan ketika berbelanja.

Semakin seseorang baik dalam penggunaan uang, hal tersebut justru dapat mengindarkan seseorang untuk berperilaku konsumtif ataupun melakukan konsumsi secara berlebihan seperti perilaku pembelian kompulsif. Semakin seseorang mampu menggunakan secara baik maka hal tersebut dapat memotivasi orang dan memengaruhi emosi pada saat memutuskan pembelian mereka (Belk \& Wallendorf, 1990; Yamauchi \& Templer, 1982). Seseorang yang mampu mengelola uang secara baik cenderung sebagai pembuat keputusan rasional dan dengan demikian individu harus selalu berusaha meningkatkan kekayaan mereka dan memaksimalkan utilitas yang dihasilkan dari uang (Finn, 1992). Oleh karena itu, sikap individu terhadap uang dan keputusan serta perilaku mereka yang melibatkan uang. Secara negatif berhubungan dengan pengambilan keputusan irasional dalam berkonsumsi (Medina et al., 1996).

Suasana hati atau mood, sering kali juga menjadi alasan mengapa seseorang melakukan pembelian kompulsif. Berdasarkan hasil penelitian atau uji signifikansi menunjukkan bahwa suasana hati secara empiris berpengaruh secara positif dan signifikan terhadap perilaku pembelian kompulsif. Hal tersebut dapat diilustrasikan bahwa keadaan suasana hati seperti bereaksi dengan rasa takut atau cemas terhadap berbagai peristiwa dalam hidup, percaya dengan hal-hal yang membuat orang lain akan suka, sering menekan diri sendiri memiliki dampak terhadap perilaku pembelian kompulsif baik senang berbelanja, berbelanja walaupun tidak membutuhkan, terus berbelanja walaupun mengalami masalah keuangan, berbelanja lebih dari pendapatan, berbelanja terhadap barang yang sama walaupun belum pernah dipakai sebelumnya, dianggap sebagai 'shopaholic', tidak merencanakan ketika berbelanja.

Perubahan suasana hati sering berdampak terhadap fenomena pembelian kompulsif, hal tersebut dapat dijelaskan karena pengalaman perubahan suasana hati yang muncul di mana-mana dan biasanya perubahan suasana hati menuju pengaruh tinggi dan menjadi keadaan gairah tinggi atau dalam hal ini adalah gairah dalam mengkonsumsi atau melakukan pembelian (Christenson et al., 1994) (McElroy et al., 1994) (Faber \& Christenson, 1996; Vohs \&Faber 2007). Beberapa penelitian menunjukkan bahwa pembeli kompulsif yang diakibatkan oleh perubahan suasana hati tidak dapat melakukan kontrol diri secara baik dalam melakukan aktivitas konsumsi (Dittmar 2005).

\section{PENUTUP}

\section{Simpulan}

Faktor-faktor psikologi sering kali memang menjadi antecendert atas perilakuperilaku negatif ataupun positif dari suatu kondisi manusia. Seperti dalam penelitian ini menunjukkan bahwa faktor-faktor psikologi seperti suasana hati dan harga diri dapat mendorong sesorang untuk melakukan tindakan irasional dalam melakukan kegiatan konsumsi. Sementara sikap seseorang dalam hal ini adalah mahasiswa ketika mereka dapat mengontro penggunaan uang secara baik maka hal tersebut secara signifikan dapat mengurangi perilaku pembelian kompulsif 
atau pembelian berlebihan. Semakin tinggi harga dan suasana hati terkadang membuat seseorang susah untuk mengontrol sikap ataupun perilaku rasional, sehingga hal tersebut berdampak pada emosi yang dimiliki sesorang meningkat.

\section{Saran}

Institusi pendidikan harus memperhatikan mahasiswa agar pendidikan tidak hanya berbasis pada konten atau isi materi semata, tetapi harus terukur capaiannya termasuk dalam hal ini perilaku rasional mereka, seperti dalam melakukan kegiatan konsumsi.

\section{DAFTAR PUSTAKA}

Barrett, L. F., \& Russell, J. A. (1999). Structure of current affect. Current Directions in Psychological Science, 8, 10-14

Baron, R.A dan Nyla R. Branscombe. 2014. Social Psychology. Thirteenth Edition. New York: McGraw Hill

Black, D. W. (2001). Compulsive buying disorder: definition, assessment, epidemiology and clinical management. CNS Drugs, 15(1), 17-27.

Brown, J.D. and Marshall, M.A. (2001). SelfEsteem and Emotion: SomeThoughts about Feelings. Personality and Social Psychology Bulletin, 27:575-584.

Cast, A.D. and Burke, P.J. (2002). A Theory of Self-Esteem, Social Forces, 80 (3):1041-1068.

Christenson, G. A., Faber, R. J., \& Mitchell, J. E. (1994). Compulsive buying: Descriptive characteristics and psychiatric comorbidity. Journal of Clinical Psychiatry, 55(12), 545-546.

Clay, Daniel.,Vivian, L. Vignoles., Helga, Dittmar. (2005). Body Image and Selfesteem Among Adolescent Girls:
Testing the Influence of Sociocultural Factors. Journal of Research. Vol 15 (4) 451-477.

Dittmar, H. (2004), "Understanding and diagnosing compulsive buying”, in Coombs, R.H. (Ed.), Handbook of Addictive Disorders: A Practical Guide to Diagnosis and Treatment, John Wiley \& Sons Inc., Hoboken, NJ, pp. 411-450.

Dittmar, H. (2005). Compulsive buying - a growing concern? An examination of gender, age, and endorsement of materialistic values as predictors. British Journal of Psychology, 96, 467-91.

Edwards, Elizabeth A. (1993). Development of New Scale For Measuring Compulsive Buying Behavior. Journal Financial Counseling And Planning, 4, 67-85.

Elliott, R. (1994). Addictive consumption: function and fragmentation in postmodernity. Journal of Consumer Policy, 17 (2), 159-179.

Faber, R. J., \& O'Guinn, T. C. (1989). Classifying compulsive consumers: advances in the development of a diagnostic tool. Advances in Consumer Research, 16(1), 738-744.

Faber, R. J., \& Christenson, G. A. (1996). In the mood to buy: Differences in the mood states experienced by compulsive buyers and other consumers. Psychology \& Marketing, 13(8), 803-819.

Finn, D. R. (1992). The Meaning of Money A View From Economics. American Behavioral Scientist, 35(6), 658-668.

Ghozali, I., Latan, H. (2014). Konsep, Metode dan Aplikasi Menggunakan Program Warp PLS 4.0 (2nd ed). Semarang : Universitas Diponegoro. 
Gora, Philemon I. (2011). Self-Esteem: Key To Personal Success. United States: Xlibris Corporation.

Kellett, S., \& Bolton, J.V. (2009). Compulsive Buiyng: A Cognitive Behavioral Model. Clinical Psychology \& Psychotherapy, 16(2), 83-99

Kyrios, M., Frost, R. O., \& Steketee, G. (2004).Cognitions in compulsive buying and acquisition. Cognitive Therapy \& Research, 28 (2), 241-258 (Lee, 2004).

Lejoyeux, M., \& Weinstein, A. (2010). Compulsive buying. The American Journal of Drug and Alcohol Abuse, 36(5), 248-253.

McElroy, S. L., Keck, P. E., Pope, H. G., Smith, J. M., \& Strakowski, S. M. (1994).Compulsive buying: a report of 20 cases. The Journal of Clinical Psychiatry, 55(6), 242-248.

Medina, J.F., Saegert, J. and Gresham, A. (1996), "Comparison of MexicanAmerican and Anglo-American attitudes toward money", The Journal of Consumer Affairs, Vol. 30 No. 1,pp. 124-46.

O'Guinn, T. C., \& Faber, R. J. (1989). Compulsive buying: A phenomenological exploration. Journal of Consumer Research, 16 (2), 147-157.

Rindfleisch, A., Burroughs, J. E., \& Denton, F. (1997). Family Structure, Materialisme, and Compulsive Consumption. Journal of Consumer Research, 23(4), 312-325.

Rosenberg, M. (1965). Society and the adolescent self-image. Princeton, NJ: Princeton University Press.

Vohs, K.D., \& Faber, R.J. (2007). Spent resources: Self-regulatory resource availability affects impulse buying. Journal of Consumer Research, 33 (4),537-547.

Yamauchi, K., and Templer, D. (1982). The development of a Money Attitudes Scale. J. Pers. Assess. 46, 522-528. 